\title{
ALK-1-positive inflammatory myofibroblastic tumor of the thyroid complicated by Hashimoto's thyroiditis: report of a rare case and a literature review
}

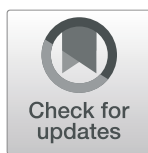

Cheng-fang $\mathrm{Li}^{1}$, Xing-long Wu${ }^{1}$, Jin-jing Wang ${ }^{1}$, Kai Wang ${ }^{1}$, Su-yuan Zhang ${ }^{1}$, Jia-jia Huang ${ }^{1}$, Han-zhong Hu${ }^{2}$ and Hong Zheng ${ }^{1 *}$

\begin{abstract}
Background: Inflammatory myofibroblastic tumors (IMTs) of the thyroid are extremely rare soft-tissue tumors. In the literature, IMTs are sometimes called plasma cell granulomas (PCGs) or inflammatory pseudotumors, which often causes ambiguity. To date, 17 cases of PCGs and five cases of thyroid IMTs have been reported. These cases reveal that IMTs of the thyroid are often negative for the anaplastic lymphoma kinase (ALK-1) gene. To provide further information on this rare lesion, we present a case of an ALK-1-positive thyroid IMT and a review of IMTs of the thyroid.
\end{abstract}

Case presentation: A 34-year-old Chinese woman presented with a painless neck mass that had persisted for over a month. Ultrasonography revealed a $4.28 \times 2.53 \mathrm{~cm}^{2}$ hypoechoic mass, in the left lobe of the thyroid gland. Serum levels of thyroglobulin and anti-thyroglobulin antibodies were high. Subsequently, left lobectomy was performed. Macroscopically, the lesion was a gray-brown nodular mass with a partial envelope. Histologically, two different lesion types were observed. The first lesion showed classic spindle cell proliferation, with spindle cells arranged in fascicles, accompanied by mature inflammatory cells. The other lesion showed a large number of infiltrating lymphocytes, with lymphoid follicles in the remaining thyroid gland, which was atrophic. Immunohistochemical staining showed that the spindle cells were negative for CK19, CyclinD1, Gelectin-3, EMA, CD34, S100, BCl-2, and STAT-6, but strongly positive for ALK-1, vimentin, and TTF1. CK was focally expressed, and the Ki-67 index was 5\%. A diagnosis of IMT was proposed according to immunohistochemical findings and morphology. Hashimoto's thyroiditis was confirmed according to serum levels of thyroglobulin and anti-thyroglobulin antibodies and morphology. The patient did not receive adjuvant therapy. She remained alive without disease recurrence for 10 months after lobectomy.

* Correspondence: zhenghonghq@hotmail.com

'Department of Pathology, the Affiliated Hospital of Zunyi Medical University, Zunyi 563000, Guizhou, China

Full list of author information is available at the end of the article

(c) The Author(s). 2020 Open Access This article is licensed under a Creative Commons Attribution 4.0 International License, which permits use, sharing, adaptation, distribution and reproduction in any medium or format, as long as you give appropriate credit to the original author(s) and the source, provide a link to the Creative Commons licence, and indicate if changes were made. The images or other third party material in this article are included in the article's Creative Commons licence, unless indicated otherwise in a credit line to the material. If material is not included in the article's Creative Commons licence and your intended use is not permitted by statutory regulation or exceeds the permitted use, you will need to obtain permission directly from the copyright holder. To view a copy of this licence, visit http://creativecommons.org/licenses/by/4.0/. The Creative Commons Public Domain Dedication waiver (http://creativecommons.org/publicdomain/zero/1.0/) applies to the data made available in this article, unless otherwise stated in a credit line to the data. 
(Continued from previous page)

Conclusions: IMTs should be considered in the diagnosis when spindle cell proliferation accompanied by mature inflammatory cells is observed, spindle cells are mildly atypical, and myofibroblast differentiation is present in the thyroid. A uniform diagnostic term is crucial to avoid ambiguity. Clinicians and pathologists should be aware of the necessity for long-term follow-up, especially in ALK-positive cases. The therapeutic potential of ALK-1 positivity should be explored further.

Keywords: Inflammatory myofibroblastic tumor, Plasma cell granuloma, ALK-1-positive, Hashimoto's thyroiditis, Case report

\section{Background}

Inflammatory myofibroblastic tumors (IMTs) are potentially malignant or low-grade malignant tumors [1]. IMTs include a heterogeneous group of lesions characterized by the proliferation of myofibroblasts with polyclonal plasma cell, lymphocyte, and eosinophil infiltrates [2]. The tumor exhibits characteristic histological features, with three distinct patterns present in the same lesion: a myxoid, vascular, and inflammatory pattern; a compact spindle cell pattern; and a dense fibrotic pattern [3].

Besides their variable morphologic patterns, IMTs also show a significant molecular heterogeneity, with over ten different anaplastic lymphoma kinase $(A L K)$ gene fusion partners identified, all of which contribute to its oncogenic activation [4-8]. ALK fusion partner genes have been identified include NPM, tropomyosin 4 (TPM4), TPM3, CLTC, TFG, ATIC, MSN, RAN binding protein 2 (RANBP2), SE31L1, CARS, and NUMA1. Oscar et al. showed that IMTs harbored kinase fusions involving ALK, ROS1, and NTRK including three novel fusion partners (KLC1, FN1, and RBPMS, respectively) in infantile forms [9]. IMT with rearrangement or translocation of the $A L K$ gene and resultant overexpression of the ALK protein, which can be detected by immunohistochemical analysis, reveals a pattern of immunohistochemical reactivity dependent on the fusion partner [9, 10]. Some cases of IMT have a tendency to relapse [11], and IMTs that are ALK-1 positive have been reported to be more aggressive [12, 13].

IMTs are usually found in the lung and upper respiratory tract, and extrapulmonary IMT has also been reported at various anatomic sites, mainly in soft tissues and the viscera [14-18]. In extrapulmonary IMT cases, head and neck lesions account for $14-18 \%$ of lesions, whereas location in the thyroid is exceedingly rare [19]. In 2006 the WHO defined IMT as an intermediary lesion with clinical recurrence and malignant potential [1]. IMTs have also sometimes been called plasma cell granulomas (PCGs) or inflammatory pseudotumors in the previous literature. PCG is a pseudotumor-like lesion characterized by polyclonal proliferation of plasma cells and intermingled with lymphocytes and other inflammatory cells in the context of fibrous tissue. This entity has an excellent prognosis with no evidence of recurrence or metastasis [10]. Mostly, the WHO classification of tumors of the lung recommends that PCG should not to be used as a synonym for IMT in the lung [20], and lesions showing a PCG morphology have not been found to show molecular abnormalities.

We found from our search of the English literature using the term IMTs of the thyroid, that there were 22 such reported cases. For all, the diagnosis was PCG and only five cases involved IMTs or inflammatory pseudotumors [13, 21-24]. These reports indicated that IMTs of the thyroid differ from those at other anatomic sites and are often negative for ALK-1. To provide further information on this rare lesion, we report a case of thyroid IMT with ALK-1 positivity and review IMTs of the thyroid. We will discuss the clinical features, diagnosis, differential diagnosis and immunohistochemical characteristics of these rare lesions. Our present report also highlights the diagnostic pitfalls in IMTs of rare anatomical sites.

\section{Case presentation}

A 34-year-old Chinese woman presented with a painless neck mass that had persisted for over a month. Physical examination on admission revealed a solid nodule with a clear boundary, measuring approximately $4 \mathrm{~cm}$, in the left lobe of the thyroid. The serum levels of thyroglobulin were high $(180.3 \mathrm{ng} / \mathrm{mL}$, normal reference range: $3.5-77 \mathrm{ng} / \mathrm{mL}$ ), as were the levels of anti-thyroglobulin antibodies $(529.7 \mathrm{IU} / \mathrm{mL}$, normal reference range: 0-115 $\mathrm{IU} / \mathrm{mL}$ ). Other indices of thyroid function were normal. Ultrasonography revealed a hypoechoic mass, $4.28 \times$ $2.53 \mathrm{~cm}$ in size, in the left lobe of the thyroid gland. The mass showed clear boundaries and a rich blood flow signal (Fig. 1). Fine-needle aspiration biopsy revealed that it could be an inflammatory hyperplastic lesion, and a left lobectomy was performed subsequently. During surgery, a solid mass, $5 \times 3 \mathrm{~cm}^{2}$ in size, was observed in the middle of the left lobe of the thyroid. The mass had a smooth surface and clear boundaries, and there was no break in the thyroid capsule. 


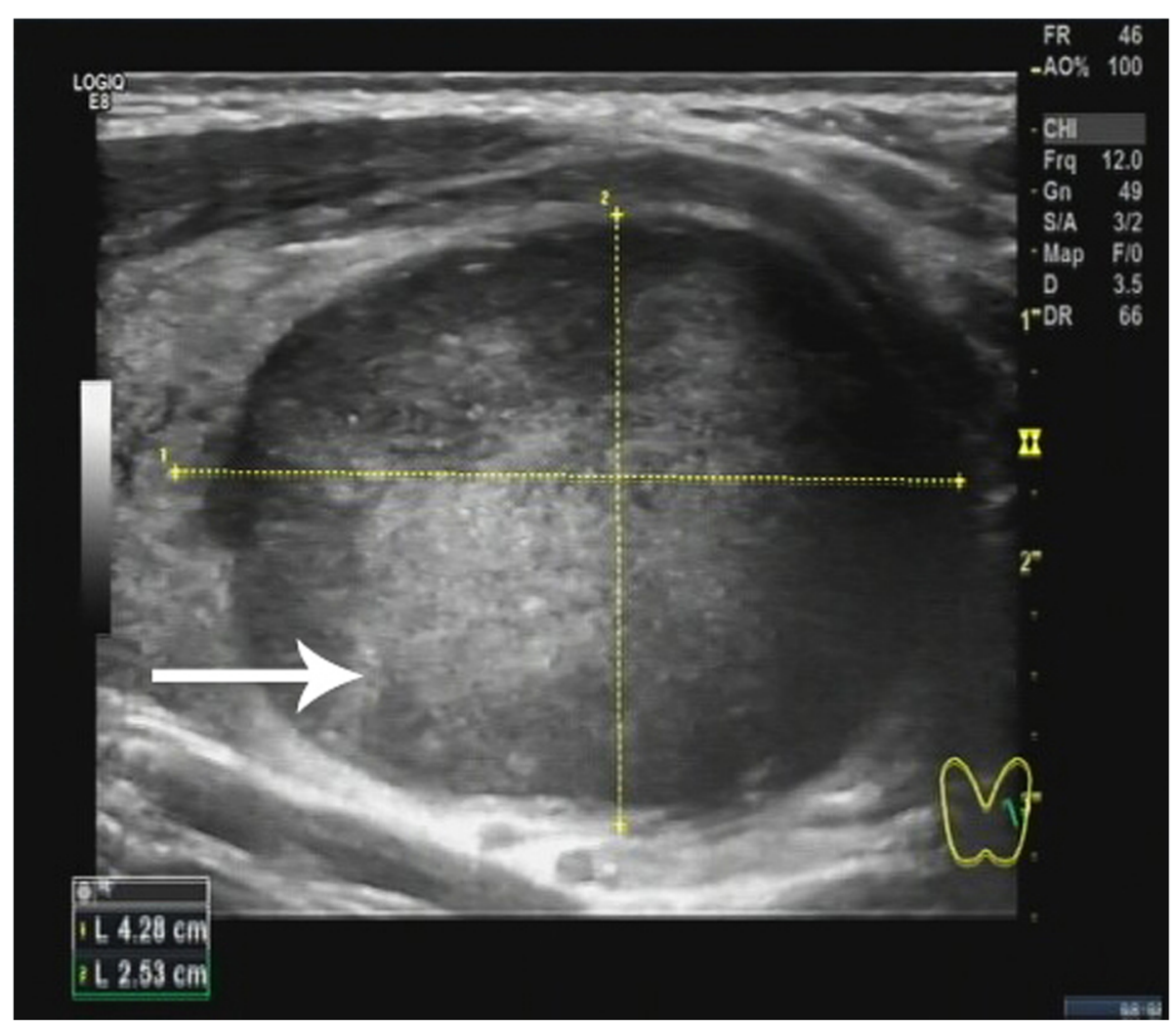

Fig. 1 Echographic examination revealed a hypoechoic mass of with clear boundary (The arrow)

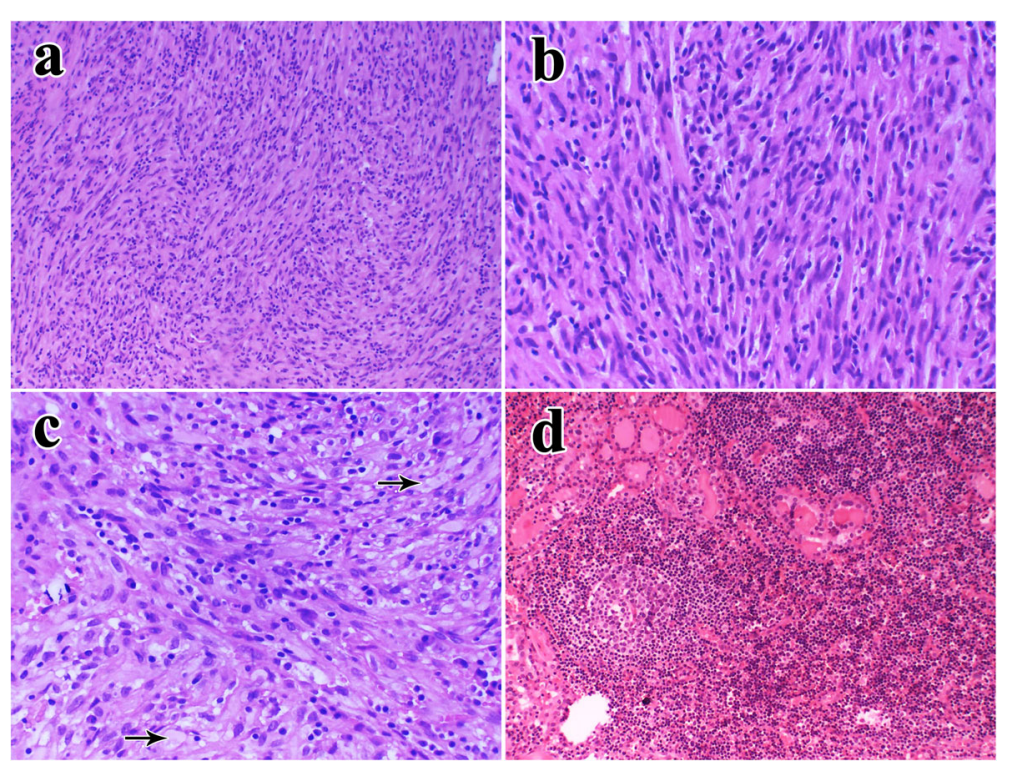

Fig. 2 Histology: a showed spindle cell proliferation accompanied by uniform distribution of inflammatory cell (100x). b These spindle cells were mildly atypia, nuclei was slightly pleomorphic (200x). c Some cells were rich in cytoplasm and translucent (The arrow, 100x). d In the remaining and atrophic thyroid gland, we found a large number of lymphocytes infiltrate and formed lymphoid of follicles (100x) 
The greatest diameter of the mass was $4.0 \mathrm{~cm}$. Macroscopically, the lesion was a gray-brown nodular mass with a partial envelope and did not infiltrate the surrounding thyroid parenchyma.

Histologically, we found two different lesions. The first lesion showed classic spindle cell proliferation, with spindle cells arranged in fascicles, accompanied by a uniform distribution of mature inflammatory cells such as plasma cells and lymphocytes (Fig. 2a). These spindle cells did not have any mitotic figures, and the nuclei were slightly pleomorphic (Fig. 2b). Focally, the stroma contained abundant hyalinized collagen. Some cells were rich in cytoplasm and were translucent, resembling histocytes (Fig. 2c). The other lesion showed a large number of lymphocyte infiltrates, with lymphoid follicles in the remaining thyroid gland, which was atrophic (Fig. $2 \mathrm{~d})$. There was a clear boundary between the two lesions. Careful observation showed that the trapped residual thyroid follicular cells had no characteristic cytological findings of papillary carcinoma.

Immunohistochemical analysis for thyroglobulin (TG), Galectin-3, CK19, CyclinD1, TTF-1, and EMA was performed to rule out the possibility of spindle cell variants of undifferentiated carcinoma of the thyroid. Of these molecules, only TTF-1 was expressed. Furthermore, CD34, S100, Bcl-2, and STAT-6 expression was negative, ruling out the possibility of a solitary fibrous tumor and malignant peripheral nerve sheath tumor (MPNST). Vimentin and ALK-1 were strongly expressed in the spindle cells (Fig. 3a). Cytokeratin (CK) and SMA were focally expressed (Fig. 3b, c), but desmin and EBV expressions were negative. Thorough examination of the thyroid was necessary considering the observed TTF-1 positivity (Fig. 3d), but no characteristics of a welldifferentiated thyroid carcinoma were found. Thus, a diagnosis of IMT was proposed on the basis of immunohistochemical findings and morphology, complicated by Hashimoto's thyroiditis on the basis of the high serum levels of thyroglobulin and anti-thyroglobulin antibodies and morphology.

The patient did not receive adjuvant therapy. Regular follow-ups with physical examinations, blood tests, and ultrasonography were performed. The patient remained well, without IMT relapse, 10 months after lobectomy.

\section{Discussion}

The thyroid gland is an extremely rare site for IMT, and only five cases have been reported in the literature to date (Table 1; to avoid conceptual confusion, PCGs were excluded). Of these five cases, two involved an ALK-1positive tumor. If we consider the present case, we can state that three of the six reported IMTs $(50 \%)$ have been ALK-1-positive.

An earlier report of thyroid PCG showed a morphological overlap with IMT [25]. However, some studies have suggested that these are distinct lesions and cannot be considered synonyms [21-23, 26].

IMTs are well recognized in the lungs and upper respiratory tract of children and young adults. They show a predilection for the first and second decades of life in other extrapulmonary IMTs [18]. The age of patients with IMT, including that in the present and previously reported cases, ranged widely from 18 to 75 years (average, 49 years), the difference may because of the limited

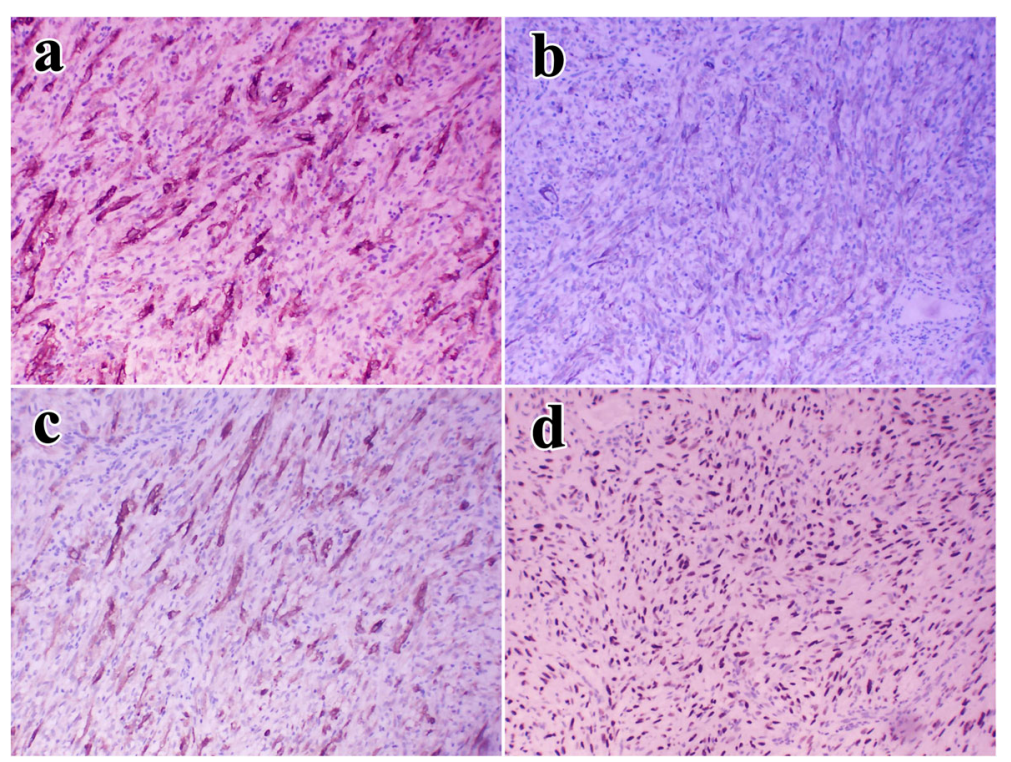

Fig. 3 Immunohistochemistry. a ALK-1 was diffusely cytoplasmic positive in spindle cells. b, c The spindle cells were focally reactive to CK (100x) and SMA (100x) respectively. $\mathbf{d}$ Focal nucleus of spindle cells were reactive to TTF1 (100x) 
Table 1 List of previously reported cases as Inflammatory myofibroblastic tumor

\begin{tabular}{|c|c|c|c|c|c|c|c|c|}
\hline $\begin{array}{l}\text { No./ } \\
\text { ref }\end{array}$ & $\begin{array}{l}\text { Age/ } \\
\text { Gender }\end{array}$ & $\begin{array}{l}\text { Histology } \\
\text { feature }\end{array}$ & Clinical presentation & HT & $\mathrm{IHC}$ & Treatment & Follow up & $\begin{array}{l}\text { Echographic } \\
\text { examination }\end{array}$ \\
\hline $1^{21}$ & $\begin{array}{l}61 / \\
\text { male }\end{array}$ & fibrohistiocytic & $\begin{array}{l}\text { Painless right thyroid } \\
\text { mass with swelling }\end{array}$ & no & $\begin{array}{l}\text { Positive: ALK-1 (cytoplasm), SMA, } \\
\text { Negative: TTF1, CK, CT, TG, S100, } \\
\text { EMA, CD34 }\end{array}$ & $\begin{array}{l}\text { Total } \\
\text { thyroidectomy }\end{array}$ & $\begin{array}{l}\text { Doing well } \\
\text { after } 1 \text { year }\end{array}$ & $\begin{array}{l}\text { Hypoechoic } \\
\text { with cystic } \\
\text { degeneration }\end{array}$ \\
\hline $2^{22}$ & $\begin{array}{l}\text { 18/ } \\
\text { Female }\end{array}$ & sclerosing & $\begin{array}{l}3 \mathrm{~cm} \text { painless mass } \\
\text { of right thyroid }\end{array}$ & no & $\begin{array}{l}\text { Positive: SMA, Vimentin,Desmin, } \\
\text { negative: EBV,S100, CD34,ALK-1 }\end{array}$ & $\begin{array}{l}\text { Subtotal } \\
\text { thyroidectomy }\end{array}$ & $\begin{array}{l}\text { No } \\
\text { recurrence } \\
9 \text { months }\end{array}$ & $\begin{array}{l}\text { Hyperechogene } \\
\text { nodule with } \\
\text { numerous } \\
\text { calcification }\end{array}$ \\
\hline $3^{23}$ & $\begin{array}{l}50 / \\
\text { female }\end{array}$ & fibrohistiocytic & $\begin{array}{l}0.6 \mathrm{~cm} \text { right thyroid } \\
\text { mass }\end{array}$ & no & $\begin{array}{l}\text { Positive: SMA, CD68 } \\
\text { Negative: TTF1, CK 19, CD34, EMA, } \\
\text { BCl2, ALK-1 }\end{array}$ & $\begin{array}{l}\text { Total } \\
\text { thyroidectomy }\end{array}$ & $\begin{array}{l}\text { Doing well } \\
1 \text { year after } \\
\text { surgery }\end{array}$ & $\begin{array}{l}\text { Hypoechoic } \\
\text { mass }\end{array}$ \\
\hline $4^{24}$ & $\begin{array}{l}75 / \\
\text { male }\end{array}$ & fibrohistiocytic & $\begin{array}{l}1.5 \mathrm{~cm} \text { painless left } \\
\text { thyroid mass for } 6 \\
\text { months }\end{array}$ & no & $\begin{array}{l}\text { Positive: Vimentin, MSA, Negative:CK, } \\
\text { Desmin, EMA, ALK-1 CycinD1, BCl-2, } \\
\text { CD99 }\end{array}$ & Left lobectomy & $\begin{array}{l}\text { Alive } \\
\text { without } \\
\text { recurrence } \\
10 \text { months }\end{array}$ & Not provide \\
\hline $5^{13}$ & $\begin{array}{l}57 / \\
\text { male }\end{array}$ & fibrohistiocytic & $\begin{array}{l}\text { Painless, } 4 \mathrm{~cm} \text { mass } \\
\text { in the right and } 3 \mathrm{~cm} \\
\text { in the left with } \\
\text { hoarseness }\end{array}$ & no & $\begin{array}{l}\text { Positive: vimentin, SMA, ALK- } \\
\text { 1((cytoplasm)) } \\
\text { Negative: CD34 }\end{array}$ & $\begin{array}{l}\text { Subtotal } \\
\text { thyroidectomy+ } \\
\text { radiation therapy+ } \\
\text { steroid therapy }\end{array}$ & $\begin{array}{l}\text { Alive with } \\
\text { recurrence } \\
\text { and } \\
\text { relapse }\end{array}$ & $\begin{array}{l}\text { Hypoechoic } \\
\text { mass and } \\
\text { heterogeneous } \\
\text { echo }\end{array}$ \\
\hline $6^{a}$ & $\begin{array}{l}34 / \\
\text { female }\end{array}$ & fibrohistiocytic & $\begin{array}{l}4 \mathrm{~cm} \text { painless left } \\
\text { thyroid mass }\end{array}$ & Yes & $\begin{array}{l}\text { Positive: ALK-1 (cytoplasm), Vimentin, } \\
\text { CK,SMA, TTF1; Negative: Desmin, } \\
\text { CK19, EBV, TG, CD34,Galectin-3, } \\
\text { STAT6, BCl-2, S100 }\end{array}$ & Left lobectomy & $\begin{array}{l}\text { Alive } \\
\text { without } \\
\text { recurrence } \\
10 \text { months }\end{array}$ & $\begin{array}{l}\text { A hypoechoic } \\
\text { mass }\end{array}$ \\
\hline
\end{tabular}

HT Hashimoto's thyroiditis, IHC Immunohistochemistry, ${ }^{\text {a }}$ Present case

number of identified cases. Our findings are consistent with those of previous reports, whereby both sexes are affected equally [27]. There were no specific symptoms related to thyroid IMT of among the 5 cases that we reviewed, all presented as painless masses, and one patient had a hoarse voice. The present case with IMT exhibited Hashimoto thyroiditis with slightly elevated thyroglobulin and anti-thyroglobulin antibody levels. However, of the five reported cases with IMT, none had no Hashimoto thyroiditis. Four showed hypoechoic nodules on ultrasonography, one showed a hyperechogenic nodule with numerous calcifications, one showed a heterogeneous echo with microcalcifications, which suggested that ultrasound examination could not easily differentiate IMT from thyroid carcinoma and infection thyroiditis.

In terms of morphology, four of the five cases that we reviewed presented a compact spindle cell pattern [24], one case exhibited a sclerosing feature. In the present case, numerous spindle cell proliferations accompanied by a uniform distribution of mature inflammatory cells in the thyroid was observed. A spindle cell neoplasm of the thyroid was considered, and spindle cell variant of papillary carcinoma of the thyroid, anaplastic carcinoma of the thyroid, and solitary fibrous tumor were included in the differential diagnoses. Immunohistochemical study is helpful in diagnosing and distinguishing IMT from other types of tumors. We excluded the possibility of these malignant tumors according to immunohistochemical markers such as thyroglobulin, CK19, MC, and
CyclinD1, all of which were found to be negative, ruling out papillary carcinoma of the thyroid. The positive result obtained for TTF-1 may have been because of the residual thyroid epithelium. Moreover, careful examination revealed no trapped residual thyroid follicular cells, which are the hallmark of papillary carcinoma. Although solitary fibrous tumors can have a similar morphology, they are positive for CD34, Bcl-2, and STAT-6 expression, but this was not observed in the present case. Finally, we also excluded the possibility of other mesenchymal tumors, such as MPNST and synovial sarcomas, through negative findings for S100 and EMA expression. It is worth mentioning that such an outcome should not exclude the limitations of our technology. Most IMTs show myofibroblast differentiation with diffusely positive vimentin and focally positive SMA and MSA in spindles, as in our patient. All five of the cases we reviewed showed positive expression for these, indicating the differentiation of myofibroblasts. Besides, expression of WT1 and D240 in the majority of inflammatory myofibroblastic tumors should be considered in the diagnostic work up to minimize misdiagnoses $[9,12]$.

Genetically, approximately $50 \%$ of IMTs harbor $A L K$ gene rearrangement with various fusion partner genes $[4,9]$. ALK immune staining appeared to be determined by its fusion partners $[9,10]$. These staining patterns include the following: perinuclear dot-like, diffuse cytoplasmic, granular cytoplasmic, nuclear membranous. ALK-1, which was diffuse and cytoplasmic positive in our case, is expressed in $36-60 \%$ of cases, and can be 
used to differentiate thyroid IMTs from other mesenchymal tumors [25]. Thus, three of the six cases (50\%; including the present case; diffuse cytoplasmic in two, granular cytoplasmic in one) involved thyroid tumors positive for ALK, which suggests that IMTs of the thyroid may not be no different from IMTs at other anatomical sites, although there is limited data regarding whether $A L K$-positive tumors differ from $A L K$-negative ones. We did not detect the rearrangement of ALK-1 because of technical limitations. More data need to be collected on these rare cases to clarify their relationship. In addition, abnormal karyotypes of tumor cells, like aneuploidy, were found in $16 \%$ of cases $[25,28]$.

The pathogenesis of IMT remains unknown, but may be related to infection or chronic inflammation [21]. Previous reports have described patients with IMT showing chronic inflammation such as leukocytosis, elevated platelet count, hypergammaglobulinemia, increase of erythrocyte sedimentation rate, and C-reactive protein $[29,30]$. In the present case, EBV expression was negative and the blood routine was normal. The patient had Hashimoto's thyroiditis, and slightly elevated thyroglobulin and anti-thyroglobulin antibodies, suggesting that the immune disorder and infection could have contributed to IMT pathogenesis. These findings were similar to those of PCG of the thyroid in previous reports; however, we did not find any thyroid IMT cases complicated by Hashimoto's thyroiditis during our review, possibly because of the limited number of cases.

Currently, the mainstream treatment of thyroid inflammatory myofibroblasts is thyroidectomy: total thyroidectomy was performed in three cases, one of which was combined with radiation therapy and oral steroid therapy for the recurrent tumors and the tumor size decreased [13], and subtotal thyroidectomy was performed in remaining three. Recent studies have suggeste that ALK-1 overexpression is associated with recurrence and invasion [31], and extra-pulmonary IMT has been reported to recur [11]. The case we reviewed suffered from local recurrence and metastasis after extensive resection [13]. Recent findings have indicated strong and durable activity of crizotinib in ALK positive IMTs regardless of the tumor location $[32,33]$. Thus, we should focus on prognosis and the therapeutic potential of ALK-1 positivity in such tumors. Except for one case with recurrence and metastasis, most patients with IMTs in the thyroid remained alive and well at the follow-up (which ranged from nine to 12 months) without disease recurrence, we recommend continuous follow-up for these patients.

\section{Conclusions}

IMT should be considered as the differential diagnosis in spindle cell lesions of the thyroid, and clinicians and pathologists should be aware of the risk of recurrence and aggressive behavior in rare cases and conduct longterm follow-up. A uniform diagnostic term is crucial to avoid ambiguity. ALK-1 positivity is not uncommon in thyroid IMT, and ALK should be used in the diagnosis and differential diagnosis of such tumors. Further studies should explore the pathogenesis and therapeutic potential of ALK-1 positivity in such tumors.

\section{Supplementary information}

Supplementary information accompanies this paper at https://doi.org/10. 1186/s13000-020-00966-4.

Additional file 1. Timeline

\section{Abbreviations}

IMT: Inflammatory myofibroblastic tumor; PCG: Plasma cell granuloma; ALK1: Anaplastic lymphoma kinase gene-1; TTF-1: Thyroid transcription factor-1; CK: Cytokeratin; EMA: Epithelial membrane antigen; STAT-6: Signal

transduction and transcriptional activator 6; $\mathrm{BCl}$-2: B-cell leukemia/lymphoma 2 gene; TG: Thyroglobulin; MPNST: Malignant peripheral nerve sheath tumor

\section{Acknowledgments \\ None.}

\section{Authors' contributions}

Cheng $L$ supervised the literature search and wrote the paper. Xing $W$. provided the interesting case that we reported. Jin W performed the followup. Kai W performed immunohistochemical tests. Su Z and Jia H evaluated the histopathological images and prepared the figures. Han $\mathrm{H}$ provided pictures of ultrasound. Hong $Z$ revised manuscript as well as guidance and editing throughout the writing process. All authors have read and approved the final manuscript.

\section{Funding}

Science and technology cooperation plan of guizhou province, guizhou science and technology cooperation LH [2015] 7556.

Availability of data and materials

As a case report, all data generated or analyzed are included in this article.

Ethics approval and consent to participate

Not applicable.

Consent for publication

Written informed consent was obtained from the patient for the publication of this case report.

Competing interests

The authors declare that they have no competing interests.

\section{Author details}

${ }^{1}$ Department of Pathology, the Affiliated Hospital of Zunyi Medical University, Zunyi 563000, Guizhou, China. ${ }^{2}$ Department of Ultrasonography, the Affiliated Hospital of Zunyi Medical University, Zunyi 563000, Guizhou, China.

Received: 10 November 2019 Accepted: 29 April 2020

Published online: 19 May 2020

References

1. Fletcher CDM. The evolving classification of soft tissue tumours: an update based on the new WHO classification. Histopathology. 2006;48:3-12.

2. Goldblum JRFA, Weiss SW. Borderline and malignant fibroblastic/ myofibroblastic tumors. Enzinger and Weiss's Soft Tissue Tumors. 6th ed. Philadelphia: Saunders/Elsevier; 2014. p. 288-340.

3. Cook JR, Dehner LP, Collins MH, Ma Z, Morris SW, Coffin CM, Hill DA. Anaplastic lymphoma kinase (ALK) expression in the inflammatory 
myofibroblastic tumor: a comparative immunohistochemical study. Am J Surg Pathol. 2001;25:1364-71.

4. Antonescu CR, Suurmeijer AJH, Zhang L, Sung Y-S, Jungbluth AA, Travis WD, Al-Ahmadie $\mathrm{H}$, Fletcher CDM, Alaggio R. Molecular characterization of inflammatory myofibroblastic tumors with frequent ALK and ROS1 gene fusions and rare novel RET rearrangement. Am J Surg Pathol. 2015;39: 957-67

5. Lovly CM, Gupta A, Lipson D, Otto G, Brennan T, Chung CT, Borinstein SC, Ross JS, Stephens PJ, Miller VA, Coffin CM. Inflammatory myofibroblastic tumors harbor multiple potentially actionable kinase fusions. Cancer Disc. 2014:4:889-95

6. Ghosh M, Islam N, Saha H, Mukhopadhyay M, Datta C, Saha K, Chatterjee U. Cytodiagnosis of inflammatory myofibroblastic tumor: a report of three cases in infants. Diagn Cytopathol. 2018;46:776-81.

7. Buccoliero AM, Ghionzoli M, Castiglione F, Paglierani M, Baroni G, Messineo A, Taddei GL. Inflammatory myofibroblastic tumor: clinical, morphological, immunohistochemical and molecular features of a pediatric case. Pathol Res Pract. 2014;210:1152-5.

8. Bridge JA, Kanamori M, Ma Z, Pickering D, Hill DA, Lydiatt W, Lui MY, Colleoni GW, Antonescu CR, Ladanyi M, Morris SW. Fusion of the ALK gene to the clathrin heavy chain gene, CLTC, in inflammatory myofibroblastic tumor. Am J Pathol. 2001;159:411-5.

9. Lopez-Nunez O, John I, Panasiti RN, Ranganathan S, Santoro L, Grélaud D, Wu T, Buccoliero AM, Casanova M, Alaggio R, Surrey LF. Infantile inflammatory myofibroblastic tumors: clinicopathological and molecular characterization of 12 cases. Modern Pathol. 2019. https://doi.org/10.1038/ s41379-41019-40406-41376.

10. Anthony PP. Inflammatory pseudotumour (plasma cell granuloma) of lung, liver and other organs. Histopathology. 1993;23:501-3.

11. Li CF, Liu CX, Li BC, Shen YY, Cui XB, Liu W, Dong HC, Pang LJ, Liang WH, Li F. Recurrent inflammatory myofibroblastic tumors harboring PIK3CA and KIT mutations. Int J Clin Exp Pathol. 2014;7:3673-83.

12. Ludwig K, Alaggio R, Dall'Igna P, Lazzari E, d'Amore ESG, Chou PM. Omental mesenteric myxoid hamartoma, a subtype of inflammatory myofibroblastic tumor? Considerations based on the histopathological evaluation of four cases. Virchows Archiv. 2015:467:741-7.

13. Duan J, Wang Y. A case report of recurrent thyroid inflammatory myofibroblastic tumor and its metastasis in soft tissue. Medicine. 2017;96: e8485.

14. Bahadori M, Liebow AA. Plasma cell granulomas of the lung. Cancer. 1973; 31:191-208

15. Jacobs D, Galetta S. Diagnosis and management of orbital pseudotumor. Curr Opin Ophthalmol. 2002;13:347-51.

16. Ruaux C, Noret P, Godey B. Inflammatory pseudotumour of the nasal cavity and sinuses. J Laryngol Otol. 2001;115:563-6.

17. Ereno C, Lopez Jl, Grande J, Santaolalla F, Bilbao FJ. Inflammatory myofibroblastic tumour of the larynx. J Laryngol Otol. 2001;115:856-8.

18. Coffin CM, Watterson J, Priest JR, Dehner LP. Extrapulmonary inflammatory myofibroblastic tumor (inflammatory pseudotumor). A clinicopathologic and immunohistochemical study of 84 cases. Am J Surg Pathol. 1995;19: 859-72.

19. Ong HS, Ji T, Zhang CP, Li J, Wang LZ, Li RR, Sun J, Ma CY. Head and neck inflammatory myofibroblastic tumor (IMT): evaluation of clinicopathologic and prognostic features. Oral Oncol. 2012;48:141-8.

20. Borezuk ACC, Fletcher CDM. Inflammatory myofibroblastic tumor. World Health Organization Classification of Tumours; vol 7. Lyon: IARC Press; 2015. p. 121-2.

21. Marylilly S, Subachitra T, Ramya V. Inflammatory Myofibroblastic Tumour of Thyroid with its Prominent Spindle Cell Pattern: A Rare Case Report. J Clin Diagn Res. 2016;10:Ed05-7.

22. Trimeche M, Ziadi S, Mestiri S, Mani R, Sriha B, Bouzouita K, Mokni M, Korbi S. Inflammatory myofibroblastic tumor of the thyroid in its sclerosing subtype: the first case report. Eur Arch Otorhinolaryngol. 2009;266:763-6.

23. Kim HJ, Na JI, Lee JS, Cho DH, Cho JS. Inflammatory myofibroblastic tumor of the thyroid gland: a brief case report. Korean J Pathol. 2014;48:319-22.

24. Kojima M, Suzuki M, Shimizu K, Masawa N. Inflammatory pseudotumor of the thyroid gland showing prominent fibrohistiocytic proliferation. A case report. Endocr Pathol. 2009;20:186-90.

25. Coffin CM, Patel A, Perkins S, Elenitoba-Johnson KS, Perlman E, Griffin CA. ALK1 and p80 expression and chromosomal rearrangements involving 2p23 in inflammatory myofibroblastic tumor. Mod Pathol. 2001;14:569-76.
26. Patil PA, DeLellis RA. Plasma cell granuloma of the thyroid: review of an uncommon entity. Arch Pathol Lab Med. 2018;142:998-1005.

27. Goto T, Akanabe K, Maeshima A, Kato R. Surgery for recurrent inflammatory pseudotumor of the lung. World J Surgical Oncol. 2011;9:133.

28. Alaggio R, Cecchetto G, Bisogno G, Gambini C, Calabrò ML, Inserra A, Boldrini R, De Salvo GL, d'Amore ES G, Dall'igna P. Inflammatory myofibroblastic tumors in childhood: a report from the Italian cooperative group studies. Cancer. 2010;116:216-26.

29. Prabhu SM, Choudhury SR, Solanki RS, Shetty GS. Multifocal intrathoracic inflammatory myofibroblastic tumour in children. Jpn J Radiol. 2012;30:453-7.

30. Ochs K, Hoksch B, Frey U, Schmid RA. Inflammatory myofibroblastic tumour of the lung in a five-year-old girl. Interact Cardiovasc Thorac Surg. 2010;10: $805-6$.

31. Coffin CM, Hornick JL, Fletcher CD. Inflammatory myofibroblastic tumor: comparison of clinicopathologic, histologic, and immunohistochemical features including ALK expression in atypical and aggressive cases. Am J Surg Pathol. 2007;31:509-20.

32. Gambacorti-Passerini C, Orlov S, Zhang L, Braiteh F, Huang H, Esaki T, Horibe K, Ahn JS, Beck JT, Edenfield WJ, Shi Y, Taylor M, Tamura K, Van Tine BA, Wu SJ, Paolini J, Selaru P, Kim TM. Long-term effects of crizotinib in ALK-positive tumors (excluding NSCLC): a phase 1b open-label study. Am J Hematol. 2018:93:607-14

33. Ogata M, Hatachi $Y$, Ogata $T$, Satake H, Imai Y, Yasui H. Effectiveness of Crizotinib for Inflammatory Myofibroblastic Tumor with ALK mutation. Int Med (Tokyo, Japan). 2019;58:1029-32.

\section{Publisher's Note}

Springer Nature remains neutral with regard to jurisdictional claims in published maps and institutional affiliations.
Ready to submit your research? Choose BMC and benefit from:

- fast, convenient online submission

- thorough peer review by experienced researchers in your field

- rapid publication on acceptance

- support for research data, including large and complex data types

- gold Open Access which fosters wider collaboration and increased citations

- maximum visibility for your research: over $100 \mathrm{M}$ website views per year

At BMC, research is always in progress.

Learn more biomedcentral.com/submissions 